\title{
Overeducation of University Graduates: A Voluntary and Rational Choice of Individuals-The Case of Three Greek Universities
}

\author{
Anastasia Pseiridis',2, Theodore P. Lianos ${ }^{3}$, George Agiomirgianakis ${ }^{*}$ \\ ${ }^{1}$ Institute for Urban Environment and Human Resources, Department of Economics \& Regional Development, Panteion \\ University, Athens, Greece \\ ${ }^{2}$ Economic Analysis and Policy Lab, School of Social Sciences, Hellenic Open University, Patras, Greece \\ ${ }^{3}$ Department of Economics, Athens University of Economics and Business, Athens, Greece \\ Email: ^gmagios@eap.gr
}

How to cite this paper: Pseiridis, A., Lianos, T.P. and Agiomirgianakis, G. (2018) Overeducation of University Graduates: A Voluntary and Rational Choice of Individuals-The Case of Three Greek Universities. Theoretical Economics Letters, 8, 2135-2156. https://doi.org/10.4236/tel.2018.811140

Received: June 27, 2018

Accepted: August 3, 2018

Published: August 6, 2018

Copyright $\odot 2018$ by authors and Scientific Research Publishing Inc. This work is licensed under the Creative Commons Attribution International License (CC BY 4.0).

http://creativecommons.org/licenses/by/4.0/ (c) (i) Open Access

\begin{abstract}
Overeducation of university graduates is considered by many theories as a market phenomenon resulting from market imbalances, market imperfections, and/or job mobility restrictions. Thus, overeducated individuals are often considered as "victims" of labor market misfunctioning, as they are not responsible for the appearance of their overeducation. On the other hand, empirical evidence suggests that overeducation 1) affects various sectors of an economy, 2) is rather large, i.e. in EU-28 it is around 30\% and 3) is persistent over time in many countries. In our paper, we take a different approach by considering overeducation as a voluntary rational choice taken by individuals when they decide their educational plans. We thus treat education not only as an investment in human capital, but also as a consumption good offering certain nonmonetary (psychic and social) benefits to university graduates. This approach suggests that overeducation may not be a temporary phenomenon and it will be higher than anticipated when considering education only as investment. Our data set is drawn from a small open economy, Greece, and it is based on graduates of three universities.
\end{abstract}

\section{Keywords}

Overeducation, Psychic Benefits from Education, Voluntary Choice, Consumption of Education, Career Mobility Theory, Human Capital Theory, Theory of Differential Overqualification 


\section{Introduction}

Overeducation or vertical mismatch occurs when an individual is hired for a job advertised as requiring a lower level of education than the individual possesses, or alternatively, when an individual is employed in a job which requires a lower level of education (see Cedefop [1]). The classical theory of human capital investment considered overeducation as an unpleasant, involuntary, small sized by-product of individuals' investment in education that will be eliminated over time (see e.g. Mc Guinness and Pouliakas [2]). However, empirical evidence suggests that overeducation is not small as the average percentage of overeducation in the EU-28 is around 19\% for medium skilled and 29\% for high skilled workers in 2013 [3], and that this high level of overeducation is persistent over time for a number of countries [1] [4]. Moreover, in this paper we suggest that overeducation is a voluntary choice and not an unpleasant by-product of investment into human capital since individuals are not only motivated in choosing their educational plans by future monetary benefits of their studies but also by certain psychic benefits arising as well from their studies and which are distinct and not related to their monetary benefits.

We examine overeducation in Greece, a country with a relatively larger overeducation percentage (29\%) compared to $19 \%$ of EU-28 in medium skilled workers and a relatively lower percentage (9\%) compared to $27 \%$ of EU-28 in highly skilled workers in 2013. Moreover, we focus our analysis on the graduates of a Greek distance learning university, the Hellenic Open University, as we have grounds to believe that psychic (i.e. non-monetary) benefits are larger for graduates that have studied at a mature age [5].

The structure of the paper is as follows: Section 2 presents some statistical data for EU-28 and Greece. In Subsection 2.1 we present theories and models that try to explain the determinants of overeducation and their common shortcoming i.e. explaining overeducation as an unpleasant characteristic of the labor markets. We also spell out, in Subsection 2.2, that overeducation may be the result of a rational choice made by individuals acting as consumers of the "educational good". Section 3 discusses our data and Section 4 the variables of our model. Section 5 presents our regression results and Section 6 provides concluding comments and policy implications.

\section{Literature Review}

There are already at least five extensive literature reviews by Linsley [6], McGuiness [7], Kucel [8], Quintini [9], and Congregado et al. [10] which provide estimates of overeducation for various countries and summaries of theories on the basis of which the persistence of overeducation can be explained.

Overeducation is a worldwide phenomenon, although its percentages differ substantially among countries. Table 1 presents minimum and maximum estimates of overeducation in some EU countries. Also, regarding European countries, Di Pietro [11] has estimated that in 13 countries the percent of overeducation 
Table 1. Recent estimates of overeducation (in \%) for various countries.

\begin{tabular}{ccc}
\hline & $\begin{array}{c}\text { Congregado et al. (2016) } \\
\text { Data refer to 1994-2001; self reported }\end{array}$ & $\begin{array}{c}\text { Flisi } \text { et al. }(2017)^{\mathrm{a}} \\
\text { Data refer to 2011-12; self-reported }\end{array}$ \\
\hline Country & 59.4 & 32 \\
Austria & 63.2 & 33 \\
Belgium & 50.8 & 50 \\
France & 64.9 & 36 \\
Germany & 60.9 & 33 \\
Denmark & 52.3 & - \\
Greece & 68.4 & 47 \\
UK & 47.2 & 27 \\
Italy & 53.5 & 43 \\
Spain & - & 27 \\
Netherlands & 44.3 & - \\
Portugal & - & 33 \\
Sweden & 62.6 & 30 \\
Finland & &
\end{tabular}

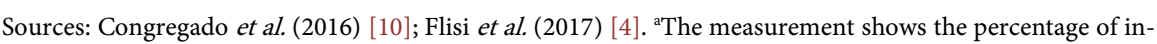
dividuals responding that "a lower level of education would be sufficient" to satisfactorily carry out one's job.

among college graduates in 1995 was between $52 \%$ and $78 \%$. More recently, Croce and Ghignoni [12] have estimated the extent of overeducation for college graduates for the period 1998-2006 to be between 30\% and 40\%. The difference between the two studies may be due to the definition used. In the Di Pietro study [11], the definition used is that of self-determination, whereas in the Croce-Ghignoni [12] study it is deviations from the mean. Flisi et al. [4] use various measurements; the most subjective measurement of overeducation provides rates ranging from $27 \%$ to $50 \%$ among various EU countries (some of them appear in Table 1), but unfortunately there is no estimate for Greece. Objective measures in Flisi et al. [4] provide overeducation rates in the range of 9\% $-17 \%$.

More specifically for Greece, there are three older studies which have estimated the extent of overeducation among university graduates. The first, by $\mathrm{Pa}$ trinos [13], has found an estimate of $16 \%$ with significant differences among sectors of employment. Two studies by Lianos et al. [14] and Lianos [15] have found estimates for overeducation of $33 \%$ and $37 \%$, respectively. More recent studies find overeducation ranging between $16 \%$ - 68\% [9] [10]. Boll etc all [3], using data refering to 2013 , find a much lower rate for post-crisis Greece, see Figure 1.

As shown in Figure 1, overeducation percentages vary from country to country with Slovakia (SK), Austria (AT), Germany (DE), UK, Croatia (HR), Czech 


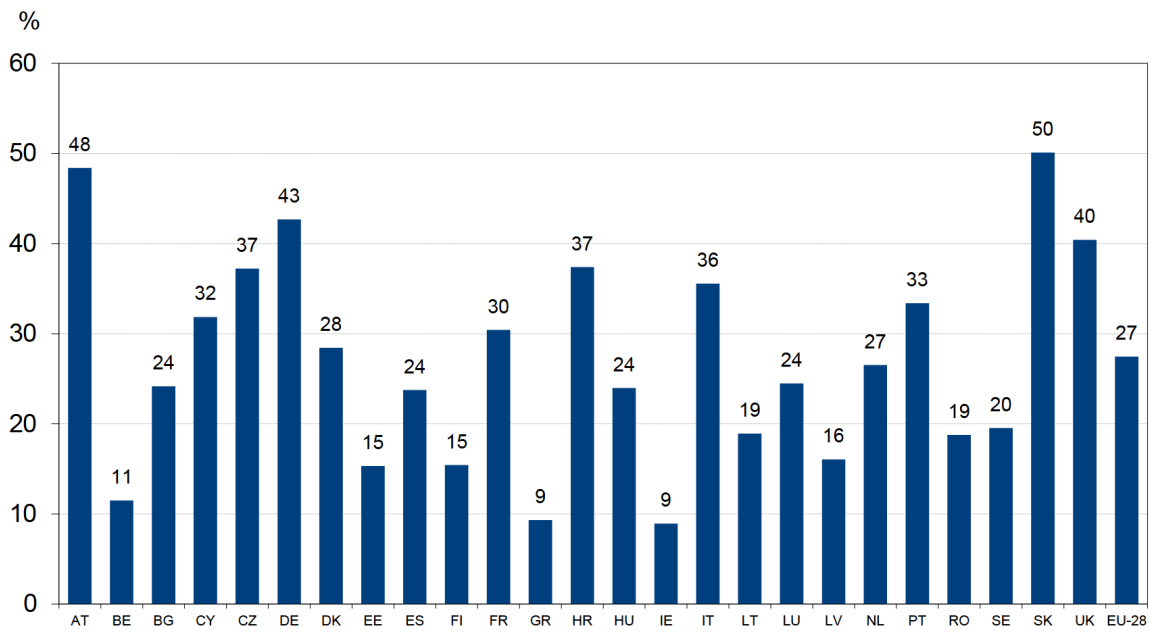

Figure 1. Overeducation of tertiary education graduates from 25 European countries, 2013. Source: reproduced from Boll et al. [3]; chart includes EU-28 without Malta, Poland and Slovenia. Data refer to 2013-15.

Republic (CZ), Italy, Poland, and Cyprus having the highest percentages of overeducation, well above the EU-28 of $27 \%$. Greece and Ireland are shown to have the lowest rate (9\%) of overeducation. As noted by Boll et al. (2016): "The exodus of well-trained young graduates from the crisis countries has created a scenario where the remaining population of high-skilled is either well matched (and therefore has no emigration incentive) or unemployed, generating the statistical result of a seemingly high matching efficiency". To examine the validity of Boll's argument we first show the Greek GDP growth from 1960 to 2016 in Figure 2 and focus our analysis in the years of the last Greek recession.

The last recession 2008-2015 has resulted to a dramatic GDP fall especially in 2011-2012 and a sharp increase in the unemployment rate, as shown in Figure 3.

The unemployment rate reached its highest level of $27.4 \%$ in $2013^{1}$. The recession of 2008-2015 in Greece has created a large emigration outflow. For the period 2007-2013 Eurostat reports that 523,363 individuals have left the country [20] while Lambrianidis and Pratsinakis [21] estimate that since 2010 approximately 650,000 young and highly skilled/qualified individuals such as medical doctors ${ }^{2}$, engineers etc. have emigrated ${ }^{3}$. The above outflows roughly represent about $5 \%$ of the total population of Greece. This large brain drain of Greece has created a relative scarcity of knowledge and skills in the Greek labor market resulting in a lower rate (9\%) of overeducation in 2013. These findings contrast with findings from previous studies conducted before the economic crisis that

\footnotetext{
${ }^{1}$ This high level of unemployment persists, although slightly declining, as Hellenic Statistical Authority reports an annual rate of $22.1 \%$ for 2017 and $20.1 \%$ for 2018 [18]. Also on the issue of unemployment persistence, the Foundation for Economic \& Industrial Research (IOBE) reports in July 2017 that $36 \%$ of those graduated from a university after 2011 are unemployed [19].

${ }^{2}$ According to the Greek Medical Association during the recession about 18,000 medical doctors have emigrated abroad (see e.g. newspaper Kathimerini 6-11-2016) [22].

${ }^{3}$ Emigration outflows are generated by large unemployment rates, wage cuts, and economic uncertainty see e.g. Labrianidis and Vogiatzis [23], Labrianidis and Pratsinakis [24], as well as Lyberaki and Tinios [25].
} 


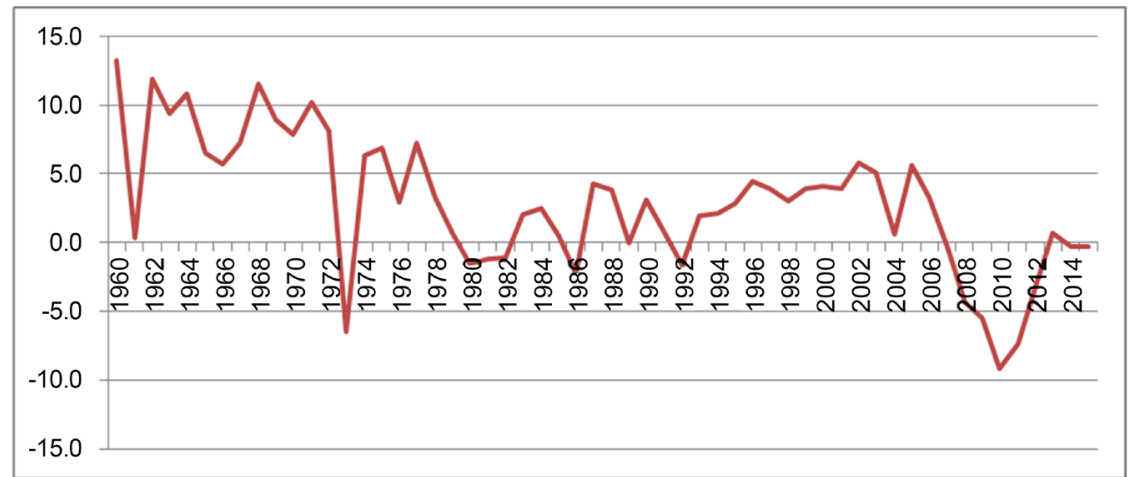

Figure 2. Greece GDP growth from 1960 to 2016. Source: AMECO database [16].

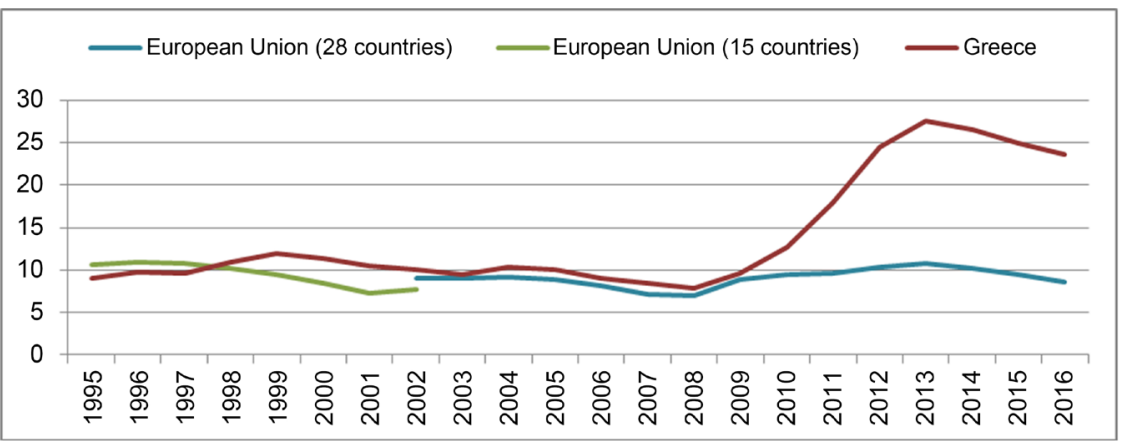

Figure 3. Unemployment rate in Greece (\%) and the EU, ages 15 - 74, all sexes and educational attainments (\%), 1995-2016. Source of data: Eurostat [17].

have estimated overeducation to be somewhere between $33 \%$ and $37 \%$ see e.g. Lianos et al. [14] [15]. In conclusion, the lower overeducation rate of 9\% in 2013 could be attributed to the brain drain phenomenon, as suggested by Boll et al. [3].

\subsection{Explaining Overeducation}

There are five theories of the potential determinants of overeducation: 1) HumanCapital Theory, 2) the Career Mobility Theory, 3) the Job Competition Theory, 4) the Assignment Theory and 5) the Mobility Restrictions models. For an overview see McGuinness and Pouliakas [2] and Boll et al. [3].

According to the Human Capital Theory (HCT) [26] [27], workers are always paid their marginal product and in equilibrium there should be no under-utilization of human capital in the labour market. In the short run, overeducation may be observed due to a temporary imbalance of job characteristics and human capital attributes or caused by a statistical artifact see e.g. Mc Guinness and Pouliakas [2]. In the long run, however, firms and individuals will make the necessary technological and administrative adjustments and imbalances will disappear.

The Career Mobility Theory [28] views overeducation as an initial stage in the career path of individuals. With time, individuals will obtain skills through on-the-job training and work experience facilitating rapid career progress in the 
future; hence, their skills will coincide with the job specifications.

The Job Competition Theory [29] suggests that firms employ the most highly educated individuals in order to avoid the cost of educating them after they are hired. However, the number of highly educated individuals is large, and there is stiff competition among them for a fixed number of jobs; thus, individuals invest in education in order to increase their chance of job recruitement. When the individual gets the job, his/her salary is predetermined by the skill requirements of the job, and is not based on the skills/qualifications level of the recruited individuals.

According to the Assignment Theory [30] overeducation can be understood as a mismatch between demand and supply of labour. Every job can be characterized by a set of attributes which are required from each worker for the performance of the job. Similarly, every worker has a set of attributes which characterize his/her supply capabilities. Taking all attributes of all jobs and all attributes of all workers, the frequency distributions of attributes demanded and of attributes supplied can be constructed. If the two distributions do not match or if the assignment mechanism is inefficient, overeducation and/or undereducation will result. In essence, this theory is based on the search cost, on behalf of the employees that make them to accept a job offer for a position below their formal skills while employers are willing to hire over skilled applicants as this may allow them to save on future training costs.

Finally, geographical, occupational or other mobility restrictions may result in overeducation, since individuals may not be able to pursue careers according to their educational qualifications. Frank [31] developed the Theory of Differential Overqualification (TDO) in an effort to explain the observed overeducation of married women. According to the TDO the husband has the first-move in accepting a job offer and then the wife follows in finding her own place in the labour market obviously facing mobility and time limitations imposed by the choice of her husband thus reducing her own career opportunities and ending up with jobs that require lower qualifications. Also, Lianos et al. [14] and Lianos [15], discuss the effect of restrictions faced bymigrants, i.e. foreign language, recognition of diplomas, work permitsetc that result in overeducation.

The above theories can explain why overeducation is a widespread phenomenon, particularly in economies where technology and consumer demand are rapidly changing. Also they imply that some human capital is lost. A common characteristic of these theories is that they treat overeducation as a market phenomenon arising from factors that are not related to the preference of individuals. Overeducated individuals are "victims" of the functioning of the labor market and of various restrictions, but are not responsible for the appearance of their overeducation.

In this study we suggest an additional reason for the existence of overeducation based on the idea that education may be a consumption good as well as an investment good. It is conceivable that some or many individuals are willing to undertake the cost of education in excess of what is needed for their professional 
objectives just for the pleasure of the educational experience. The fact that the observed overeducation is so extensive leads to the idea that it may not be due to the malfunctioning of the labor market but it may be the result of rational choice on the part of individuals as consumers. We believe that by taking this point of view, overeducation will no longer be seen as an unpleasant temporary phenomenon driven by market imperfections, but rather as a voluntary choice of individuals acting as consumers.

\subsection{Education as a Consumption Good}

Education is usually seen as an investment, but there is reason to believe that part of the benefits accruing to the individual can be non-monetary, i.e. psychic and social. Of course, the relative importance of monetary and non-monetary benefits for an individual may depend on the value system of a given society and the individual's natural propensities. In any event, the psychic benefits are not only felt during the schooling period but also they continue to be present after graduation. These benefits can be gained through attending classes, studying, discovering new knowledge, enhancing one's understanding of a topic, socializing with intellectually stimulating professors and colleagues during studies and in later life, etc. The social benefits are felt mainly after the schooling period, through the heightened social status that is associated with a university degree, which becomes a permanent characteristic of the graduate for the rest of his/her life. It can be argued that holding a university degree may be seen as a positional good because it advances the relative standing of the holder within society [32] [33].

Therefore, if education also provides psychic and social benefits, students may attend or stay in school longer than necessary, not only for their professional purposes, but personal purposes as well. A student may enroll in a European Literature study program simply because he/she enjoys the study of literature even though it is uncertain that a relevant job will be available after his/her graduation. Also, a student may stay longer in the program to receive a MA degree or a $\mathrm{PhD}$ knowing that it is unlikely to use that knowledge in the expected career as a high school teacher. Moreover, some students will not necessarily and accurately connect studies with job prospects. In other words, if education is considered by some people as a consumption good providing utility, it may be demanded independently of, or in combination with, expected monetary benefits.

Given that education has monetary and nonmonetary benefits, it can be considered as an investment good that brings increased future earnings and/or as a consumption good purchased by those who have higher incomes and a taste for education. The literature on the monetary benefits is practically limitless. However, on the nonmonetary benefits arising from education we have been able to locate only a few studies. In an early paper, Lazear [34] examined this question: Is the positive relationship between education and earnings a result of the fact that education increases the earning capacity of individuals, or is it because individuals with higher incomes buy more goods, one of which is education? Lazear 
reaches the conclusion that education in fact increases the ability of individuals to increase their earnings. Alternatively, a second conclusion is that education is a "bad".

More recently, Oosterbeek \& van Ophem [35] estimated that education has a positive effect on utility, which is evidence of education being a consumption good. They also found that the effect of education on utility is larger than that of lifetime earnings by $26 \%$ for 13 - 16 years of schooling (which corresponds to 3 4 years of University education) and $28 \%$ for more than 16 years of schooling. Alstadsæter [36] examined Swedish individuals who studied during the 60s. Among individuals of the same academic calibre, those who opted to study education (and subsequently work as teachers) sacrificed $35 \%$ of the expected lifetime income of those who attended Business School. Thirty years following this educational decision, the actual wages foregone were even higher: $41 \%$ of the wages of those who opted for Business School. Similarly, Alstadsæter \& Sievertsen [37] using US data find that Liberal Arts graduates in the US earn only 54\% of what they could earn. The income foregone can be seen as payment for consumption value derived from the choice of a specific course of study. The above studies suggest that opting for a program that offers lower expected lifetime earnings can be seen to imply that education is a "good" (i.e. offers consumption value), at least for some people.

\section{Data}

In the present study we examine the extent of overeducation among graduates who have received their degree from a distance learning university (the Hellenic Open University, HOU thereafter) and two traditional universities (University of Macedonia and University of Crete)which require the physical presence of their students.

Our data are drawn from a larger database created through questionnaires which were collected between July and October 2015. A link to the questionnaire was sent to graduates who graduated in 2007, 2008, and 2009. This means the questionnaire was filled-in 6-8 years after graduation. The questionnaire consisted of a large array of questions, including motivations for study, perceived benefits, financial situation and earnings for 4 years pre-graduation and 4 years post-graduation, work characteristics, job satisfaction, academic aptitude, and family characteristics. In total, 832 questionnaires were collected from people who had completed a first degree without further study (master's or PhD). 712 graduates came from HOU and 120 from the traditional universities. Graduates came from three academic programs, namely Management Studies, Computer Science, and Civilization and Humanities Studies. We should note here the major differences between the two types of university. In HOU, students are enrolled through a random selection process among applicants who must be 25 years of age or older and pay tuition fees. Students in traditional universities are enrolled following successful participation in national-level examinations at the 
age of 18 and do not pay fees.

From the collected sample of 832 graduates, 464 graduates (379 from HOU and 85 from the traditional universities) reported having jobs relevant to their field of study i.e. vertical mismatch is absent. We thus used this subset of graduates to examine our hypothesis that overeducation may be partly due to voluntary choices of individuals.

A possible weakness of the dataset is that, due to budget limitations, the survey for the collection of data from graduates was conducted among graduates from only three Greek Universities. Cost considerations did not allow us to include graduates from all Greek universities or from similar foreign universities, but this could be attempted in future research. However, the two traditional universities we selected can be seen as adequately representing the average Greek university. Further, we cannot make sure that our sample does not suffer from selection bias. On the other hand, the questionnaire was sent to a random subset of the graduates. As it contained a wide range of questions, it is likely that the questionnaire itself did not attract or preclude specific kinds of graduates from completing it. Despite its limitations, our research may be useful in initiating discussion and research on the link between overeducation and the non-monetary benefits arising from the consumption of education.

\subsection{Overeducation}

The decision as to whether an individual is overeducated or not was based on the answer given to the following question:

"The knowledge you have is more or less than that required for the performance of your job in the position you hold?"

With three possible answers:

1) I have more knowledge than required;

2). I have exactly the knowledge required; and

3) I have less knowledge than required.

Thus the estimates of overeducation we received are subjective measures. This method of measuring overeducation has been criticized as lacking rigorous instructions and thus allowing individuals to overstate the requirements of the job they perform in order to inflate the status of their position [38]. Also, overeducated workers may be less interested in responding to questionnaires because of job apathy. On the other hand, individuals may instead report deflated requirements of their job, which yields an inflated percentage of overeducated workers [7]. However, despite these disadvantages, the subjective method has the advantage of collecting information for the person with the more complete knowledge about the situation.

The following tables of descriptive statistics provide some information for the extent of overeducation among respondents. Table 2 shows that $57 \%$ of graduates perceive that they are overeducated for the job they perform.

Table 3 and Table 4 show overeducation by age and work experience, respectively. One would expect overeducation to decline, since age and work experience 
Table 2. Percentage of overeducation by gender.

\begin{tabular}{ccccc}
\hline \multicolumn{5}{c}{ My knowledge is ... } \\
\hline & $\begin{array}{c}\text {... more than needed } \ldots \text { the same as needed } \\
\text { for my job }\end{array}$ & for my job & $\begin{array}{c}\text { less than needed } \\
\text { for my job }\end{array}$ & Total \\
\hline Males & $150(63 \%)$ & $77(32 \%)$ & $10(4 \%)$ & $237(100 \%)$ \\
Females & $108(50 \%)$ & $97(45 \%)$ & $9(4 \%)$ & $214(100 \%)$ \\
Total & $258(57 \%)$ & $174(39 \%)$ & $19(4 \%)$ & $\mathbf{4 5 1 ( 1 0 0 \% )}$ \\
\hline
\end{tabular}

Source: Our questionnaire data. Respondents have jobs suited to their study field.

Table 3. Overeducation by age.

\begin{tabular}{|c|c|c|c|c|}
\hline Age group & & My knowledge is ... & & Total \\
\hline & $\begin{array}{l}\text {... more than needed } \\
\text { for my job }\end{array}$ & $\begin{array}{l}\text {.... the same as needed } \\
\text { for my job }\end{array}$ & $\begin{array}{l}\text {... less than needed } \\
\text { for my job }\end{array}$ & \\
\hline$<30$ & $6(24 \%)$ & 15 & 4 & 25 \\
\hline $30-34.9$ & $23(43 \%)$ & 28 & 2 & 53 \\
\hline $35-39.9$ & $37(62 \%)$ & 22 & 1 & 60 \\
\hline $40-44.9$ & $55(58 \%)$ & 35 & 5 & 95 \\
\hline $45-49.9$ & $62(55 \%)$ & 46 & 4 & 112 \\
\hline $50-54.9$ & $51(75 \%)$ & 14 & 3 & 68 \\
\hline $55-59.9$ & $22(59 \%)$ & 14 & 1 & 37 \\
\hline $60-$ & $3(100 \%)$ & 0 & 0 & 3 \\
\hline Total & $259(57 \%)$ & 174 & 20 & 453 \\
\hline
\end{tabular}

Table 4. Years of total work experience.

\begin{tabular}{ccccc}
\hline $\begin{array}{c}\text { Yrs of work } \\
\text { experience }\end{array}$ & \multicolumn{3}{c}{ My knowledge is ... } & Total \\
\hline & $\begin{array}{c}\text {.. more than } \\
\text { needed for my job }\end{array}$ & $\begin{array}{c}\text {... the same as } \\
\text { needed for my job }\end{array}$ & $\begin{array}{c}\text {. less than needed } \\
\text { for my job }\end{array}$ & \\
\hline$<5$ & $8(44 \%)$ & 10 & 0 & 18 \\
$5-9.9$ & $35(44 \%)$ & 38 & 6 & 79 \\
$10-14.9$ & $33(62 \%)$ & 17 & 3 & 53 \\
$15-19.9$ & $43(58 \%)$ & 30 & 1 & 74 \\
$20-24.9$ & $46(58 \%)$ & 27 & 7 & 80 \\
$25-29.9$ & $43(70 \%)$ & 16 & 2 & 61 \\
$30-34.9$ & $11(58 \%)$ & 8 & 0 & 19 \\
$35-$ & $5(63 \%)$ & 3 & 0 & 392 \\
Total & $224(57 \%)$ & 149 & 19 & \\
\hline
\end{tabular}

increase as the employees have more opportunities to find a job suited to their qualifications. Contrary to this expectation, our data show no specific pattern.

Table 5 shows the occurrence of overeducation by work position. There seems to be no clear pattern linking overeducation to specific positions. 
Table 5. Overeducation by position in work hierarchy.

\begin{tabular}{ccccc}
\hline & \multicolumn{4}{c}{ My knowledge is ... } \\
\hline Sectors & $\begin{array}{c}\text {... more than } \\
\text { needed for my job }\end{array}$ & $\begin{array}{c}\text {... as needed for my } \ldots \text { less than needed } \\
\text { for my job }\end{array}$ & Total \\
\hline Unskilled worker & $1(50 \%)$ & $1(50 \%)$ & $0(0 \%)$ & 2 \\
Skilled worker & $1(50 \%)$ & $0(0 \%)$ & $1(50 \%)$ & 2 \\
Employee & $119(56 \%)$ & $84(39 \%)$ & $10(5 \%)$ & 213 \\
Superintendent & $60(64 \%)$ & $33(35 \%)$ & $1(1 \%)$ & 94 \\
$\begin{array}{c}\text { Managerial staff } \\
\text { Self employed, owner, } \\
\text { shareholder, other }\end{array}$ & $25(55 \%)$ & $19(42 \%)$ & $1(3 \%)$ & 45 \\
Total & $33(52 \%)$ & $24(38 \%)$ & $6(10 \%)$ & 63 \\
All except managerial staff & $214(57 \%)$ & $142(38 \%)$ & $18(5 \%)$ & 374 \\
$\begin{array}{c}\text { Employees and } \\
\text { superintendents }\end{array}$ & $179(58 \%)$ & $117(38 \%)$ & $11(4 \%)$ & 307 \\
\hline
\end{tabular}

\subsection{Psychic Benefit as an Explanatory Variable}

As it has been stated above, we consider the psychic benefit from education as an explanatory variable of overeducation for people who are employed in jobs relevant to their study field ${ }^{4}$. Furthermore, we assume that the benefits from education can be grouped into three categories: monetary benefits, social status benefits, and psychic benefits. We also assume that individuals can give subjective estimates of the relative significance (percentage-wise) of the above three benefits of education.

In our questionnaire, there were two questions related to the value university graduates give to their university education. The first question was phrased as follows:"Today, having had the experience of your studies, would you attend university if you knew that your degree would not offer you any monetary benefits?"The possible answers to the question were: "Yes"; "Most likely yes"; "Most likely no"; "No"; "Do not know/Cannot tell".

To the first question, the answers "Yes" and "Most likely yes" were chosen by $91 \%$ of the Hellenic Open University graduates and by $82 \%$ of conventional universities graduates. This indicates a clear evidence of non-monetary benefits arising from university studies for the overwhelming majority of graduates.

The second question was directed more to the benefits from university education and was phrased as follows: "From your studies you have acquired monetary benefits (higher earnings, better work conditions, increased employability, etc.), social benefits (status, connections, etc.), and psychic benefits. How do you evaluate these, percent wise? (The sum of the three must be equal to $100 \%$ )."

The answers to the second question are presented in Table 6.

It is seen from Table 6 that psychic benefit has the highest percentage among

${ }^{4}$ The case of horizontal mismatch will be investigated in future research. 
Table 6. Monetary, social, and psychic benefit as a $\%$ of total benefit.

\begin{tabular}{ccc}
\hline Benefits & $\begin{array}{c}\text { Breakdown of benefits } \\
\text { Hellenic Open University graduates } \\
(\mathrm{n}=374)\end{array}$ & $\begin{array}{c}\text { Breakdown of benefits } \\
\text { Graduates of traditional universities } \\
(\mathrm{n}=66)\end{array}$ \\
\hline Monetary benefit & $28 \%($ s.d. $=21)$ & $36 \%($ s.d. $=17)$ \\
Social benefit & $18 \%($ s.d. $=13)$ & $28 \%($ s.d $=12)$ \\
Psychic benefit & $53 \%($ s.d. $=22)$ & $36 \%($ s.d. $=15)$ \\
Total benefit & $100 \%$ & $100 \%$ \\
\hline
\end{tabular}

Source: Our questionnaire data. Respondents have jobs suited to their study field. Note: the three benefits sum up to $100 \%$ of the respondents' benefit from their degree.

HOU graduates, and is of equal importance for conventional graduates. It is also interesting that in these direct estimates, the non-monetary benefits (psychic and social) relative to the monetary benefit is 2.5 for HOU graduates and 1.7 for other graduates. The psychic benefit alone, is larger than the other two combined for HOU graduates only. In other words, the psychic benefit of university graduates constitutes a considerable part of the total benefit from education, but this effect is stronger for HOU graduates.

The following graph, derived from the data in Table A1, shows the distribution of responses regarding benefits. It can be seen that for the monetary benefit and social benefit the majority (90\% for social benefit and 66\% for monetary benefits) of responses place these two types of benefits below $40 \%$ of total benefit; while the majority (72\%) of responses about psychic benefit place it at, or above, $40 \%$ of total benefit. It is clear that more than $70 \%$ of respondents indicated a psychic benefit of $40 \%$ or more, while $66 \%$ of respondents indicated a monetary benefit of $40 \%$ or less. Impressively, $90 \%$ of responses gave to social benefit a relative weight of less than $40 \%$ (Figure 4 ).

\section{Variables and Regression Results}

In what follows we describe the variables we have used in our analysis.

\subsection{Overeducation}

In the regression estimation which we present below, overeducation as the dependent variable is a dummy defined as $\mathrm{Y}=1$ if the respondent has classified him/herself as overeducated (having more knowledge than needed for one's job) and zero otherwise.

The independent variables are defined as follows.

\subsection{Personal Preference for Education}

Psychic benefit and social status acquired from education are the two variables we introduce in this study as explanatory variables of overeducation. The variable "psychic benefit" measures the subjective value of psychic benefits and variable "social benefit" measures the subjective value of the social status acquired by the university degree. The questionnaire question was constructed in a way that 


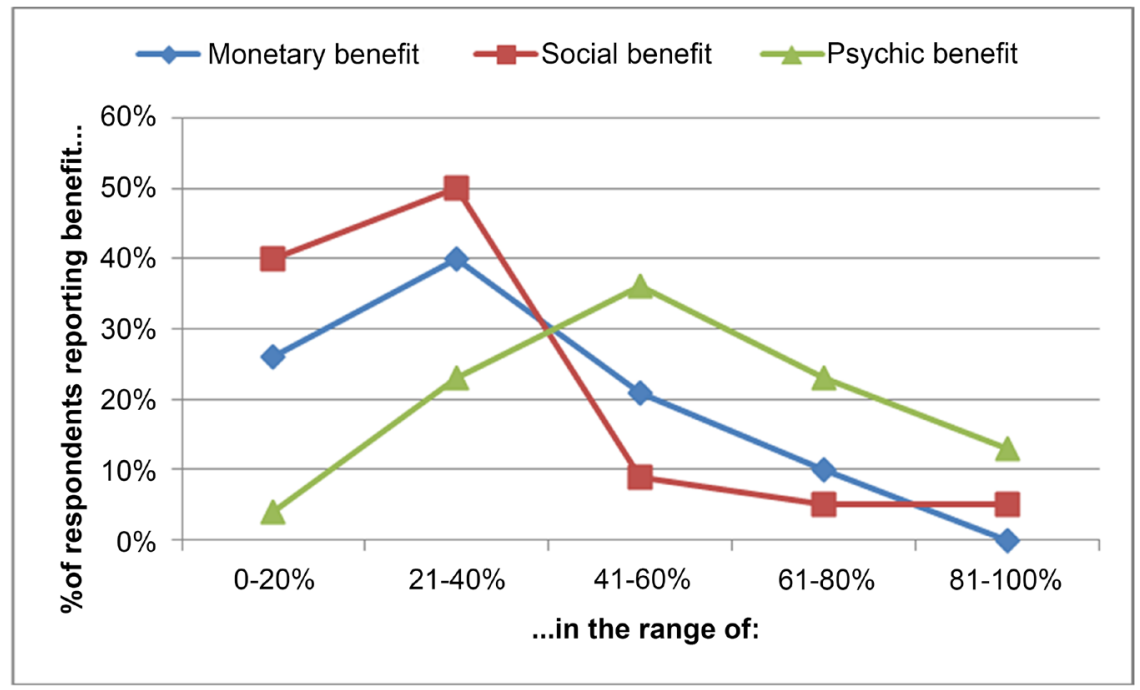

Figure 4. Distribution of benefits. Note: Vertical axis shows percentage of respondents. The data that have been used for this graph can be found in Table A1 in the Appendix.

total benefits (psychic, social, monetary) would add up to 1 , by definition. Hence, these benefits variables take values between 0 and 1 . These two variables are used to test our hypothesis that people value education and derive utility from it independently of the monetary benefits resulting from university studies. Thus, they are prepared for the possibility of not finding a job for which they are qualified and are willing to be employed in jobs for which they are overeducated. If education is also consumption good, part of overeducation in employment is a result we should expect and accept as a natural result of people's preferences. Therefore we expect both variables to be positively related with overeducation.

\subsection{Gender}

The effect of gender on overeducation is ambiguous. Women may accept jobs for which they consider themselves overeducated, because they are not as career oriented or they face geographic or other restrictions (e.g. they are more likely to spend more time than male for domestic responsibilities such as child and elderly care and household maintenance). At the same time, since the main earner of a family is usually male, women may have less pressure and more time to search for a job that fits their specific qualifications. On the other hand, men may be forced to accept a job for which they are overeducated because of the pressure and responsibility to be the main household earner. The dummy variable in our model takes the value of 1 for females. We have also incorporated interaction terms of gender (see Appendix), but their inclusion does not change the significance of the psychic and social benefits.

\subsection{Age and Work Experience}

One characteristic which differentiates HOU graduates from those of the traditional universities is that they often work before they begin their studies. Thus, if 
they continue to work at the same employer and job they are, by definition, overeducated. The possibility of taking a new job depends on the conditions of the labor market and the restrictions (e.g. loss of seniority) on mobility. Further, work experience might be associated with more income to be spent on consumption goods, including education. On the other hand, the longer the work experience, the higher the probability of the employee being hired for a job in accordance with his/her qualifications. Thus, in the case of the Hellenic Open University graduates' work experience may have an ambiguous effect. As few respondents provided their work experience, we use their age as a proxy variable of work experience. The Pearson correlation coefficient of age and work experience is $0.7(\mathrm{p}<0.001)$.

\subsection{Family and Kids}

The probability of accepting a job for which one is overeducated might be higher for parents. Also, since women tend to assume the role as primary caregiver for a child, having children might make women more willing to accept job positions mismatched to their education level. On the other hand, since women might completely withdraw from the labor market to raise their children, they might remain out of the labor market until they find a job that matches their education level.

\subsection{Study Programs}

Graduates of various study programs may be overeducated, depending on the situation of the markers for their qualification and the diversity of jobs for which they are qualified. We expect graduates of the Management study program to be overeducated to a lesser extent than the graduates of the European Civilization program. We used two dummy variables (one for Management Studies, and one for Civilization studies). The base category (omitted in the regression) is the Computers study program.

\subsection{Employer Changes}

An employee who has found a job according to his qualifications does not need to change jobs unless better job opportunities are offered. However, an employee may have found a proper job after many employer changes. Thus the effect of this variable is ambiguous. The variable "employer changes" is coded as [1] [2] [3] [4] and measures the numbers of times one has changed jobs, namely one, two, three, four or more.

\subsection{Position in Work Environment}

Overeducation may be related with the position one holds within the work environment. It can be expected that as a person moves to a managerial position his/her job might be more suited to his/her education level. We, thus, have classified work positions in two categories: managerial and non-managerial. 


\section{Regression Results}

The regression has been estimated using a log it model with heteroscedasticity robust standard errors. Table 7 presents odds ratios.

From Table 7 it can be seen that the odds for being overeducated increase when psychic or social benefit increase (significance at the $5 \%$ level), indicating that the probability of being overeducated is higher for those who receive utility from education. More specifically, a person whose benefit is purely psychic has almost 4 times the chances of reporting themselves as overeducated than a person whose psychic benefit is 0 . The odds ratio of social status is also larger than 1 and significant at the $5 \%$ level. Our findings show that a person who reports that

Table 7. Regression results, reported as odds ratios.

\begin{tabular}{|c|c|c|c|c|c|c|c|c|}
\hline & \multicolumn{2}{|c|}{$\mathrm{R} 1$} & \multicolumn{2}{|c|}{$\mathrm{R} 2$} & \multicolumn{2}{|c|}{$\mathrm{R} 3$} & \multicolumn{2}{|c|}{ R1 \& R3 sample } \\
\hline Variables & $\begin{array}{l}\text { Odds } \\
\text { ratios }\end{array}$ & $\mathrm{z}$ & $\begin{array}{l}\text { Odds } \\
\text { ratios }\end{array}$ & $\mathrm{z}$ & $\begin{array}{l}\text { Odds } \\
\text { ratios }\end{array}$ & $\mathrm{z}$ & $\begin{array}{l}\text { Average } \\
\text { value }\end{array}$ & range \\
\hline $\begin{array}{l}\text { Dependent variable: } \\
\text { Overeducation }\end{array}$ & & & & & & & 0.59 & $0-1$ \\
\hline \multicolumn{9}{|l|}{ Independent variables: } \\
\hline $\begin{array}{l}\text { Social benefits of } \\
\text { education }\end{array}$ & $6.012^{* *}$ & 2.04 & $6.878^{\star *}$ & 2.22 & $6.443^{* *}$ & 2.09 & 0.19 & $0-0.8$ \\
\hline $\begin{array}{c}\text { Psychic benefits of } \\
\text { education }\end{array}$ & $3.621^{\star *}$ & 2.14 & $3.951^{\star *}$ & 2.35 & $4.097^{\star *}$ & 2.31 & 0.50 & $0-1$ \\
\hline Female & $0.609^{* *}$ & -1.98 & $0.593^{\star *}$ & -2.12 & 0.869 & -0.32 & 0.48 & $0-1$ \\
\hline Age & $1.042^{*}$ & 1.76 & $1.043^{*}$ & 1.86 & $1.041^{\star}$ & 1.70 & 42.9 & $28-59$ \\
\hline Married & $\ldots$ & $\cdots$ & 1.324 & 1.05 & 1.847 & 1.28 & 0.70 & $0-1$ \\
\hline Number of children & 0.978 & -0.17 & $\ldots$ & $\ldots$ & 0.931 & -0.35 & 1.26 & $0-4$ \\
\hline \multicolumn{9}{|l|}{ Interactions } \\
\hline Female with kids & $\ldots$ & $\ldots$ & $\ldots$ & $\ldots$ & 0.862 & -0.51 & 0.54 & $0-4$ \\
\hline Female and married & $\cdots$ & $\cdots$ & $\ldots$ & $\cdots$ & 0.818 & -0.32 & 0.30 & $0-1$ \\
\hline HOU graduate & 0.737 & -0.67 & 0.589 & -1.14 & 0.675 & -0.84 & 0.84 & $0-1$ \\
\hline $\begin{array}{c}\text { Study program: } \\
\text { Management Studies }\end{array}$ & 0.809 & -0.76 & 0.846 & -0.61 & 0.774 & -0.91 & 0.58 & $0-1$ \\
\hline \multicolumn{9}{|l|}{ Study program: } \\
\hline $\begin{array}{c}\text { Civilisation \& Literature } \\
\text { Studies }\end{array}$ & 0.520 & -1.42 & 0.523 & -1.45 & 0.504 & -1.45 & 0.09 & $0-1$ \\
\hline $\begin{array}{c}\text { No of employer changes } \\
\text { after graduation }\end{array}$ & 0.928 & -0.58 & 0.922 & -0.62 & 0.928 & -0.57 & 1.45 & $0-4$ \\
\hline $\begin{array}{c}\text { Managerial position at } \\
\text { work }\end{array}$ & $0.496^{*}$ & -1.89 & $0.532^{*}$ & -1.70 & $0.504^{\star}$ & -1.86 & 0.11 & $0-1$ \\
\hline Constant & $0.139^{* *}$ & -2.08 & $0.116^{* *}$ & -2.30 & 0.143 & -1.98 & & \\
\hline Pseudo $\mathrm{R}^{2}$ & 0.0453 & & 0.0501 & & 0.0526 & & & \\
\hline Observations & 330 & & 341 & & 330 & & & \\
\hline
\end{tabular}

Note: ${ }^{\star},{ }^{*}$, and ${ }^{* *}$ denote significance at the $10 \%, 5 \%$, and $1 \%$ level, respectively. “..." means "not used". 
his/her benefit is purely social has 5 times more chances to report themselves as overeducated as compared to a person whose social benefit is 0 . Both these results provide support to the idea that non-monetary benefits are important motivators in the decision of individuals to engage in university study. Therefore, these results provide strong support for the hypothesis introduced in this paper, that overeducation can be partly explained by viewing education as consumption as well as investment.

Regarding the personal characteristics, the odds ratio for female gender is less than 1 and significant; it seems that females are $40 \%$ less likely than males to be overeducated. This could be an indication of a relatively uneven availability of free time between the two genders. Females usually take up a larger part of domestic responsibilities, hence less time is available for consumption of activities such as education. Also, since women opt out of the labor market to raise children, the lower levels of overeducation a might be an indication that they re-enter the labor market when they find a job which fits their specific qualifications. Our finding is in contrast with the Theory of Differentical Overqualification [30] according to which women face a limited set of employment choices therefore are more likely to accept positions for which they are overqualified.

The effect of age, which has been used as a proxy for work experience, is larger than land significant at the $10 \%$ level. This suggests that age might increase the likelihood for overeducation. This finding could be explained as follows: an employee having a relatively large work experience already enjoys employability and relatively higher wages. This might mean that, to large extend, his/her monetary aspirations have already been materialized and, therefore, more income is available to be used in pleasurable activities, the consumption of education being one of them. Our finding contrasts with the Career Mobility Theory [27] which suggests that overeducation is reduced with age.

The number of children is insignificant. We have run the same regression with marital status (where married takes the value of 1), but this variable was insignificant as well see R2. We also run the same regression with interactions of marital status, female gender, and number of children, see R3. These additional results do not, however, alter our main findings, that the presence of psychic and/or social benefit increases the likelihood of overeducated individuals.

The probability of being overeducated does not seem to be affected by the university type (distance learning vs. traditional) or the study field. Also, the number of times an individual has changed an employer does not affect it. That probably shows that graduates are primarily concerned with the task to be employed as Job Competition theory predicts.

Finally, the position of the individual within the work hierarchy is a significant variable. Managerial staff are less likely to be overeducated in contrast with the broad variety of individuals ranging from technicians, employees, superintendents, to self-employed people. This finding is in line with the Career Mobility Theory [27]. 
Table 8 summarizes the effects of psychic benefit, social benefit, type of work position held, and age, on overeducation by showing the predicted probability for overeducation that corresponds to different values of these variables. As the average value for overeducation in our sample is 0.59 (59\%), some simplified highlights would be that a person has an above average probability of being overeducated when:

1) Their reported psychic benefit is $50 \%$ or more.

Table 8. Predicted probability for overeducation by gender.

\begin{tabular}{|c|c|c|c|}
\hline \multirow[t]{2}{*}{ Significant variable and values } & \multicolumn{3}{|c|}{ Predicted probability for overeducation } \\
\hline & Both genders & Males & Females \\
\hline \multicolumn{4}{|l|}{ Level of reported psychic benefit } \\
\hline 0 & 0.44 & 0.50 & 0.38 \\
\hline 0.2 & 0.50 & 0.56 & 0.44 \\
\hline 0.4 & 0.57 & 0.62 & 0.50 \\
\hline 0.6 & 0.63 & 0.68 & 0.57 \\
\hline 0.8 & 0.68 & 0.74 & 0.63 \\
\hline 1.0 & 0.74 & 0.78 & 0.69 \\
\hline \multicolumn{4}{|l|}{ Level of reported social benefit } \\
\hline 0 & 0.51 & 0.57 & 0.45 \\
\hline 0.2 & 0.60 & 0.66 & 0.54 \\
\hline 0.4 & 0.68 & 0.73 & 0.63 \\
\hline 0.6 & 0.76 & 0.80 & 0.71 \\
\hline 0.8 & 0.82 & 0.85 & 0.77 \\
\hline 1.0 & 0.86 & 0.89 & 0.83 \\
\hline \multicolumn{4}{|l|}{ Position in work hierarchy } \\
\hline Non-managerial position & 0.62 & 0.67 & 0.55 \\
\hline Managerial position & 0.44 & 0.50 & 0.38 \\
\hline \multicolumn{4}{|l|}{ Age } \\
\hline 28 & 0.45 & 0.50 & 0.38 \\
\hline 30 & 0.47 & 0.53 & 0.40 \\
\hline 35 & 0.52 & 0.58 & 0.45 \\
\hline 40 & 0.57 & 0.63 & 0.51 \\
\hline 45 & 0.62 & 0.67 & 0.56 \\
\hline 50 & 0.67 & 0.72 & 0.61 \\
\hline 55 & 0.71 & 0.76 & 0.65 \\
\hline 60 & 0.75 & 0.79 & 0.70 \\
\hline
\end{tabular}

Note: The three benefits add up to 1, by definition. Calculations of predicted probabilities are based on Regression 1 and made under the assumption that all other variables take the value of the sample mean (reported in Table 7). 
2) Their reported social benefit is $20 \%$ or more.

3) They hold a non-managerial position.

4) They are over 43 yrs of age.

\section{Concluding Comments and Policy Implications}

Overeducation among university graduates is a widespread phenomenon in many countries. Several explanations have been suggested. In this study we have introduced the preference for education as an additional element in people's life that may partly explain overeducation. Our findings, based on a dataset collected from the graduates of three Greek universities, provide empirical support to the idea that there are psychic and social status benefits from education that students pursue independently of the monetary benefits associated with university education and, therefore, they are less concerned with becoming and being overeducated.

Our regression results show that both the psychic benefits and the social benefits variables are positive and significant (in statistical and actual terms) in explaining perceived overeducation. Thus, in addition to the explanations stated in the literature section, namely that of the short-run disequilibrium phenomenon, or as an aspect of professional career etc., the preference of individuals for education for the psychic and social status benefits might appear to be a factor explaining part of the observed high overeducation rates in many European economies.

In fact, if people value education and derive utility from it (independently of the monetary benefits resulting from university studies), they should be prepared for the possibility of being employed in jobs for which they are overeducated. In other words, overeducation in employment may partly be a result of people's preference for education. In such a case, overeducation would not necessarily be a result of malfunctioning of the labor market and the allocation of graduates across jobs may not be sub-optimal. That is, the extra motivation for pursing university education generated by psychic and social benefits results in overeducation. Moreover, the increasing standards of living in European countries allow people to spend more time on education, that is, to treat education as a consumption good; which, in turn results in higher levels and persistence of overeducation over time.

\section{Highlights}

1) Overeducation percentages are widespread in different sectors of an economy, they are high and they persist overtime. To explain these stylized facts we introduce "preference for education", describing the psychic benefit of graduates, as an explanatory variable of the observed overeducation.

2) In the presence of psychic benefit overeducation is indeed a voluntary choice of individuals when they decide their educational plans.

3) We examine the extent of overeducation among graduates of three Greek 
universities.

4) A person has an above average probability of being overeducated when their reported psychic benefit is $50 \%$ or more of their total benefit from education.

5) A person has an above average probability of being overeducated when their reported social benefit is $20 \%$ or more of their total benefit from education.

6) Females are $40 \%$ less likely to be overeducated.

7) A person has an above average probability of being overeducated when they hold a non-managerial position. A person has an above average probability of being overeducated when they are over 43 yrs of age.

\section{Acknowledgements}

This research was carried out as a research project co-financed by the European Union (European Social Fund-ESF) and Greek national funds through the Operational Program "Education and Lifelong Learning" of the National Strategic Reference Framework (NSRF). Financial support is gratefully acknowledged. We are thankful to anonymous referees for insightful comments and useful suggestions and to Genevieve Gorgos for editorial assistance.

\section{Conflicts of Interest}

The authors declare no conflicts of interest regarding the publication of this paper.

\section{References}

[1] Cedefop (2010) The Skill Matching Challenge: Analyzing Skill Mismatch and Policy Implications. Publications Office of the European Union, Luxembourg.

[2] McGuinness, S. and Pouliakas, K. (2016) Deconstructing Theories of Overeducation in Europe: A Wage Decomposition Approach. Discussion Paper No. 9698 February 2016 IZA.

[3] Boll, C., Leppin, A., Rossen, A. and Wolf, A. (2016) Overeducation-New Evidence for 25 European Countries. Institute for Employment and Research, IAB Discussion Paper 35/2016.

[4] Flisi, S., Goglio, V., Meroni, E., Rodrigues, M. and Vera-Toscano, E. (2017) Measuring Occupational Mismatch: Overeducation and Overskill in Europe, Evidence from PIAAC. Social Indicators Research, 131, 1211-1249. https://doi.org/10.1007/s11205-016-1292-7

[5] Pseiridis, A., Lianos, T.P. and Agiomirgianakis, G.M. (2018) Is University Education an Investment or a Consumption Good? Forthcoming in International Journal of Education Economics and Development.

[6] Linsley, I. (2006) Causes of Overeducation in the Australian Labour Market. Australian Journal of Labor Economics, 8, 121-143.

[7] McGuinness, S. (2006) Overeducation in the Labour Market. Journal of Economic Surveys, 20, 387-418. https://doi.org/10.1111/j.0950-0804.2006.00284.x

[8] Kucel, A. (2011) Literature Survey of the Incidence of Overeducation: A Sociological Approach. Revista Española de Investigaciones Sociológicas (REIS), 134, 125-142. 
http://www.reis.cis.es/REIS/PDF/Reis_134_061302519925436.pdf

[9] Quintini, G. (2011) Over-Qualified or Under-Skilled: A Review of Existing Literature. OECD Social, Employment and Migration Working Papers No. 121 (Paris, OECD). https://doi.org/10.1787/5kg58j9d7b6d-en

[10] Congregado, E., Iglessias, J., Millán, J.M. and Román, C. (2016) Incidence, Effects, Dynamics and Routes Out of Overqualification in Europe: A Comprehensive Analysis Distinguishing by Employment Status. Applied Economics, 48, 411-445. https://doi.org/10.1080/00036846.2015.1083080

[11] Di Pietro, G. (2002) Technological Change, Labor Markets and Low-Skill Low-Technology Traps. Technological Forecasting and Social Change, 69, 885-895. https://doi.org/10.1016/S0040-1625(01)00182-2

[12] Croce, G. and Ghignoni, E. (2012) Demand and Supply of Skilled Labor and Overeducation in Europe: A Country-Level Analysis. Comparative Economic Studies, 54, 413-439. https://doi.org/10.1057/ces.2012.12

[13] Patrinos, H. (1997) Overeducation in Greece. International Review of Education, 24, 203-223. https://doi.org/10.1023/A:1002981301802

[14] Lianos, T.P., Asteriou, D. and Agiomirgianakis, G. (2004) Foreign Universities Graduates in the Greek Labor Market: Employment, Salaries and Overeducation. International Journal of Finance and Economics, 9, 151-164. https://doi.org/10.1002/ijfe.238

[15] Lianos, T.P. (2007) Brain Drain and Brain Loss: Immigrants to Greece. Journal of Ethnic and Migration Studies, 33, 129-140. https://doi.org/10.1080/13691830601043562

[16] Ameco Database. Series: Gross Domestic Product at 2010 Reference Levels (OVGD).

[17] Eurostat. Unemployment Rates by Sex, Age and Educational Attainment Level (\%). http://ec.europa.eu/eurostat/tgm/table.do?tab=table\&plugin=1\&language=en\&pcod e=tepsr_wc170

[18] Hellenic Statistical Authority (2018) Labour Force Survey 2004-2018. http://www.statistics.gr/en/statistics?p_p_id=documents_WAR_publicationsportlet _INSTANCE_qDQ8fBKKo4lN\&p_p_lifecycle $=2 \& p \_p \_s t a t e=$ normal\&p_p_mode $=\mathrm{v}$ iew\&p_p_cacheability=cacheLevelPage $\&$ p_p_col_id=column-2\&p_p_col_count $=4$ \&p_p_col_pos=1\&_documents_WAR_publicationsportlet_INSTANCE_qDQ8fBK Ko4lN_javax.faces.resource=document\&_documents_WAR_publicationsportlet_IN $\underline{\text { STANCE_qDQ8fBKKo4lN_ln=downloadResources\&_documents_WAR_publicatio }}$ nsport-

let_INSTANCE_qDQ8fBKKo4lN_documentID=321731\&_documents_WAR_publi cationsportlet_INSTANCE_qDQ8fBKKo4lN_locale=en

[19] Eurostat (2018) Emigration by Age Group, Sex and Citizenship. http://appsso.eurostat.ec.europa.eu/nui/show.do?dataset=migr_emilctz\&lang=en

[20] Foundation for Economic \& Industrial Research (IOBE) (2017) Higher Education in Greece: The Crisis Consequences and Challenges. (In Greek) http://iobe.gr/docs/research/RES_05_F_05072017_REP_GR.pdf

[21] Labrianidis, L. and Pratsinakis, M. (2016) Greece's New Emigration at Times of Crisis. GreeSE Paper 99, Hellenic Observatory Papers on Greece and Southeast Europe, London School of Economics and Political Science, London.

[22] Bouloutza, P. (2016) Doctors Continue Their Migration in 2016. http://www.kathimerini.gr/882319/article/epikairothta/ellada/metanasteyoyn-oi-gia 
troi-kai-to-2016

[23] Labrianidis, L. and Vogiatzis, N. (2013) Highly Skilled Migration: What Differentiates the "Brains" Who Are Drained from Those Who Return in the Case of Greece? Population, Space and Place, 19, 99472-99486.

[24] Labrianidis, L. and Pratsinakis, M. (2013) The Mutually Reinforcing Relation between International Migration of Highly Educated Labour Force and Economic Crisis: The Case of Greece. Southeast European and Black Sea Studies, 13, 525-551.

[25] Lyberaki, A. and Tinios, P. (2017) Small Firms as a Blind Spot in Greek Austerity Economics. IDS Working Paper 491, Institute of Development Studies.

[26] Becker, G.S. (1964) Human Capital: A Theoretical and Empirical Analysis with Special Reference to Education. 3rd Edition, The University of Chicago Press, Chicago.

[27] Mincer, J.A. (1974) Schooling, Experience, and Earnings. National Bureau of Economic Research, New York.

[28] Sicherman, N. (1991) "Overeducation" in the Labor Market. Journal of Labor Economics, 9, 101-122. http://www.jstor.org/stable/2535236 https://doi.org/10.1086/298261

[29] Thurow, L. (1975) Generating Inequality: Mechanisms of Distribution in the U.S. Economy. Basic Books, New York.

[30] Sattinger, M. (1993) Assignment Models of the Distribution of Earnings. Journal of Economic Literature, 31, 831-880. http://www.jstor.org/stable/2728516

[31] Frank, R.H. (1978) Why Women Earn Less: The Theory and Estimation of Differential Overqualification. American Economic Review, 68, 360-373.

[32] Pagano, U. (1999) Is Power an Economic Good? Notes on Social Scarcity and the Economics of Positional Goods. In: Bowles, S., Franzini, M. and Pagano, U., Eds., The Politics and the Economics of Power, Routledge, London, 116-145.

[33] Schneider, M. (2007) The Nature, History and Significance of the Concept of Positional Goods. History of Economics Review, 45, 60-81. http://www.hetsa.org.au/pdf/45-A-4.pdf

[34] Lazear, E.P. (1977) Education: Consumption or Production. Journal of Political Economy, 85, 569-597. https://doi.org/10.1086/260584

[35] Oosterbeek, H. and van Ophem, H. (2000) Schooling Choices: Preferences, Discount Rates and Rates of Return. Empirical Economics, 25, 15-34.

https://doi.org/10.1007/s001810050002

[36] Alstadsæter, A. (2011) Measuring the Consumption Value of Higher Education. CESifo Economic Studies, 57, 458-479. https://doi.org/10.1093/cesifo/ifq009

[37] Alstadsæter, A. and Sievertsen, H.H. (2009) The Consumption Value of Higher Education. CESifo Working Paper Series 2871, CESifo Group Munich. http://ssrn.com/abstract=1521425

[38] Hartog, J. (2000) Over-Education and Earnings: Where Are We, Where Should We Go? Economics of Education Review, 19, 131-147. 


\section{Appendix}

Table A1. Relative weights for monetary, social, and psychic benefit $(n=440)$.

(a)

\begin{tabular}{ccccccc}
\hline \multicolumn{6}{c}{ No of respondents reporting benefit in the range of ... } \\
\hline $\begin{array}{c}\text { Range of benefit } \\
(0-100)\end{array}$ & $0 \%-20 \%$ & $21 \%-40 \%$ & $41 \%-60 \%$ & $61 \%-80 \%$ & $81 \%-100 \%$ & Row total \\
\hline $\begin{array}{c}\text { Monetary benefit } \\
\text { Social benefit }\end{array}$ & 116 & 175 & 94 & 44 & 11 & 440 \\
Psychic benefit & 18 & 222 & 38 & 2 & 1 & 440 \\
\hline
\end{tabular}

(b)

$\%$ of respondents reporting benefit in the range of ...

\begin{tabular}{ccccccc}
\hline $\begin{array}{c}\text { Range of benefit } \\
(0-100)\end{array}$ & $0 \%-20 \%$ & $21 \%-40 \%$ & $41 \%-60 \%$ & $61 \%-80 \%$ & $81 \%-100 \%$ & Row total \\
\hline $\begin{array}{c}\text { Monetary benefit } \\
\text { Social benefit }\end{array}$ & $26 \%$ & $40 \%$ & $21 \%$ & $10 \%$ & $2.5 \%$ & $100 \%$ \\
Psychic benefit & $4 \%$ & $50 \%$ & $9 \%$ & $<1 \%$ & $<1 \%$ & $100 \%$ \\
\end{tabular}

